Original Research Article

\title{
Anxiolytic activity of ethanolic and aqueous extract of Ficus carica Linn fruits in swiss albino mice
}

\author{
Chandrashekar K. ${ }^{1 *}$, Amudha $\mathbf{P}^{2}$, Venkataraman $\mathrm{S}^{2}$
}

${ }^{1}$ Department of Pharmacology, Chettinad Hospital and Research Institute, Kelambakkam, Kanchipuram 603103, Tamil Nadu, India

${ }^{2}$ Department of Pharmacology, C.L. Baid Metha College of Pharmacy, Okkiyam, Thuraipakkam, Chennai 600097 , Tamil Nadu, India

Received: 09 June 2017 Accepted: 07 July 2017

\section{*Correspondence to: \\ Dr. Chandrashekar K., Email: chandrashekarshkr61@ gmail.com}

Copyright: (C) the author(s), publisher and licensee Medip Academy. This is an openaccess article distributed under the terms of the Creative Commons Attribution NonCommercial License, which permits unrestricted noncommercial use, distribution, and reproduction in any medium, provided the original work is properly cited.

\begin{abstract}
Background: Benzodiazepams are mainly used to treat anxiety but these drugs produce serious adverse effects, hence herbal drugs are preferred. The present study was undertaken to evaluate the anti-anxiety activity of ethanolic and aqueous extract of Ficus carica (FC) Linn fruits in swiss albino mice.

Methods: Male swiss albino rats weighing 25-30gms were divided into six groups and six animals in each group. Diazepam $(1.0 \mathrm{mg} / \mathrm{kg})$, AEFC (200 and $400 \mathrm{mg} / \mathrm{kg}$ ) and EEFC (200 and $400 \mathrm{mg} / \mathrm{kg}$ ) were suspended in $1 \%$ gum acacia and administered orally. The EEFC and AEFC (both extracts at 200 and $400 \mathrm{mg} / \mathrm{kg} / \mathrm{p} .0$ ) and vehicle were administered for 7 days once daily p.o. and the last dose was given on the 7lh day, $60 \mathrm{~min}$ prior to exposure to the experimental paradigms viz., Elevated plus maze, T- maze model and Hole -board model.

Results: Both the extracts of FC significantly increased the number of entries into, time spent and rears in the open arms. Also, it increased the percentile ratio of open arm to total arm entries in elevated plus maze. In T- maze, the both the extracts FC showed a significant increase in baseline latency and decrease in escape and avoidance. In the hole-board model a significant increase in the exploratory behavior like head-dipping and line crossing, rearing was observed after treatment with EEFC and AEFC. FC also decreases the nor-adrenaline levels and increase in serotonin and dopamine levels in the brain. These behavioural changes were significantly higher than that produced by the standard anxiolytic drug diazepam.

Conclusions: It was concluded that ethanolic and aqueous extracts of Ficus carica fruits having antianxiety activity.
\end{abstract}

Keywords: Anxiety, Elevated plus maze, Ficus carica, T- maze model and Hole -board model

\section{INTRODUCTION}

Anxiety is an emotional state, unpleasant in nature, associated with uneasiness, discomfort and concern or fear about some defined or undefined future threat. Anxiety affects most of the population nearly one-eighth of the total population world-wide. Benzodiazepines, being major class of compounds used for treatment of anxiety, present a narrow margin of safety between the anxiolytic effect and unwanted side effects, has prompted researchers to evaluate new compounds specially plant based drugs having less undesirable effects. ${ }^{1,2}$

Ficus carica Linn. belongs to the family Moraceae, which is commonly referred as "Fig", grows in tropical and subtropical regions of India. In traditional medicine the roots are used in treatment of leucoderma and ringworms and its fruits which are sweet, have antipyretic, purgative, 
aphrodisiac properties and have shown to be useful in inflammations and paralysis. . $^{3,4}$

$F$. carica has been reported to have various bioactive compounds such as arabinose, $\beta$-amyrins, $\beta$ - carotines, glycosides, $\beta$-setosterols and xanthotoxol psoralen, bergapten, umbelliferone, campesterol, stigmasterol, fucosterol, fatty acids, 6-(2- methoxy-Z-vinyl)-7-methylpyranocoumarin and 9,19-cycloarlane triterpenoid as an and antiproliferative agent: 6-Oacyl- $\beta$-Dglucosyl - $\beta$ sitosterol, calotropenyl acetate and lupeol acetate. ${ }^{5}$

In addition, several therapeutic effects have been shown for different parts of Ficus carica, such as hypoglycemia, anthelmintic, hypotriglyceridemia and hypocholestrolemia. ${ }^{6-9}$ Hence this study was planned to evaluate the anxiolytic activity of ethanolic and aqueous extract of Ficus carica Linn fruits in swiss albino mice.

\section{METHODS}

\section{Plant extract preparation}

\section{Ethanolic extract}

Fruits were air dried under shade at room temperature for 30 days and milled into a coarse powder. The obtained $100 \mathrm{~g}$ of air dried powder was subjected to continuous extraction with $500 \mathrm{ml}$ of $95 \% \mathrm{v} / \mathrm{v}$ ethanol in a Soxhlet apparatus. It was extracted with ethanol for 15 cycles about 18-20 $\mathrm{hr}$ and solution was evaporated to dryness under reduced pressure and controlled temperature by using rotoevaporator. The extract was stored in a refrigerator at $4{ }^{\circ} \mathrm{C}$ in air-tight bottles until further use.

\section{Aqueous extract}

The fruits were powdered and extracted with water by maceration process. The extract thus obtained was concentrated to dryness in a flash evaporator under reduced pressure and controlled temperature. The extract was stored in the refrigerator seperately.

Both the extracts were suspended in $1 \%$ gum acacia and used for the experiments.

\section{Drugs and chemicals}

Diazepam tablets, aqueous and ethanolic extracts of Ficus carica (AEFC and EEFC).

\section{Animals}

Adult male Swiss albino mice weighing 25-30g from our breeding stock were used in this study. The animals were housed at $24 \pm 2{ }^{\circ} \mathrm{C}$ with $12: 12 \mathrm{~h}$ light and dark cycle. They had free access to food and water. The animals were acclimatized for a period of seven days before the study. The animals were used according to the CPCSEA guidelines for the use and care of experimental animals.

\section{Experimental design}

108 adult swiss albino mice weighing 25-30gms were selected.36 animals were allocated elevated plus maize test, 36 animals to $\mathrm{T}$ - maize test and remaining 36 to Hole -board test. In each model there were 6 groups of 6 animals in each. The group 1 received vehicle (1\% gum acacia $10 \mathrm{ml} / \mathrm{kg} \mathrm{P.O})$, group 2, standard drug Diazepam $(1 \mathrm{mg} / \mathrm{kg}$ P.O.), group 3 and 4 , received the ethanolic extract $(200$ and $400 \mathrm{mg} / \mathrm{kg}$ P.O respectively) and group 5 and 6 , received aqueous extract $(200$ and $400 \mathrm{mg} / \mathrm{kg}$ P.O respectively) of Ficus carica.

The EEFC and AEFC (both extracts at 200 and $400 \mathrm{mg} / \mathrm{kg} / \mathrm{p} . \mathrm{o}$ ) and vehicle were administered for 7 days once daily p.o. and the last dose was given on the 7lh day, $60 \mathrm{~min}$ before starting the experiment (Table 1).

Table 1: Experimental design.

\begin{tabular}{|lll|}
\hline Groups & Drugs & Dose \\
\hline Group 1 & 1\% gum acacia & $10 \mathrm{ml} / \mathrm{kg}$ P.O. \\
\hline Group 2 & Diazepam & $1 \mathrm{mg} / \mathrm{kg} \mathrm{P.O.}$ \\
\hline Group 3 & $\begin{array}{l}\text { Ethanolic extract of } \\
\text { Ficus carica }\end{array}$ & 200mg/kg P.O. \\
\hline Group 4 & $\begin{array}{l}\text { Ethanolic extract of } \\
\text { Ficus carica }\end{array}$ & 400mg/kg P.O. \\
\hline Group 5 & $\begin{array}{l}\text { Aqueous extract of } \\
\text { Ficus carica }\end{array}$ & 200mg $/ \mathrm{kg}$ P.O. \\
\hline Group 6 & $\begin{array}{l}\text { Aqueous extract of } \\
\text { Ficus carica }\end{array}$ & 400mg/kg P.O. \\
\hline
\end{tabular}

\section{Evaluation of anti-anxiety activity}

\section{Elevated Plus Maze Model (EPM)}

EPM consists of two open arms $(50 \mathrm{~cm} \times 10 \mathrm{~cm})$ and two closed arms $(50 \mathrm{~cm} \times 10 \mathrm{~cm} \times 40 \mathrm{~cm})$. The arms same type was opposite to each other with a central square of $10 \mathrm{~cm}$. The maze was elevated to a height of $50 \mathrm{~cm}$ above the floor. Each animal was placed in the centre square of plus maze, facing one of the open arms. The number of entries in open and closed arms by the animal in a 5 minutes period was noted. ${ }^{10,11}$

Every precaution was taken to ensure that no external stimuli, other than the height of the plus-maze could invoke mice anxiety. After each trial, the elevated plusmaze apparatus was wiped clean with ethanol $10 \%$ solution.

\section{T-Maze Model}

T- Maze is made of black painted wood or grey plastic. Each arm is $40 \mathrm{~cm}$ long, $13 \mathrm{~cm}$ high, $3 \mathrm{~cm}$ wide at the bottom, $10 \mathrm{~cm}$ wide at the top and converges at an equal angle. For a period of $5 \mathrm{~min}$ the behavior of the mouse was recorded as the time of baseline latency, escape and avoidance. Mice were allowed to socialize. After each 
trial, the T-maze apparatus was wiped clean with ethanol $10 \%$ solution. $^{12}$

\section{Hole-board Model}

The apparatus consists of a wooden box $(40 \times 40 \times 25 \mathrm{~cm})$ with 16 holes (each of diameter $3 \mathrm{~cm}$ ) evenly distributed on the floor. The apparatus was elevated to a height of $25 \mathrm{~cm}$. For a period of $10 \mathrm{~min}$. the number of line crossing and number of head dipping and rearing were calculated. After each trial, the Hole board apparatus was wiped clean with ethanol $10 \%$ solution. $^{13}$

\section{Estimation of dopamine and nor-adrenaline levels in mice brain by spectrofluorimetry}

\section{Preparation of tissue extract}

On $7^{\text {th }}$ the day of experiment the animals were sacrificed, whole brain was dissected out and separated the subcortical region (including the striatum). Weighted a specific quantity of the tissue and was homogenized in 3 $\mathrm{ml}$ of Hcl Butanol in a cool environment. The sample was then centrifuged for $10 \mathrm{~min}$, at $2000 \mathrm{rpm}$. $0.8 \mathrm{ml}$ of the supernatant phase was removed and added to an Eppendorf reagent tube containing $2 \mathrm{ml}$ of heptane and $0.25 \mathrm{ml}$ of $0.1 \mathrm{MHcl}$.

After 10 min., shake the tube and centrifuged under same condition to separate two phases. The upper organic phase was discarded and the aqueous phase was used for dopamine and nor-adrenaline assay.

\section{Estimation of dopamine and nor-adrenaline}

To $0.02 \mathrm{ml}$ of $\mathrm{Hcl}$ phase, $0.005 \mathrm{ml}$ of $0.4 \mathrm{M} \mathrm{Hcl}$ and $0.0 \mathrm{ml}$ EDTA / Sodium Acetate buffer $(\mathrm{pH}$ 6.9), followed by
$0.01 \mathrm{ml}$ iodine solution for oxidation. The reaction was stopped after $2 \mathrm{~min}$ by the addition of $0.1 \mathrm{ml}$ sodium thiosulphate in 5M Sodium hydroxide. Acetic acid was added 1.5 min later.

The solution was then heated to $100^{\circ} \mathrm{C}$ for $6 \mathrm{~min}$. When the sample again reaches room temperature, excitation and emission spectra were studied (330 to $375 \mathrm{~nm}$ for Dopamine and 395 to 485 for NA) in a spectrofluorimeter.

\section{Estimation of serotonin}

$3 \mathrm{mg}$ of brain was homogenized in $\mathrm{HCl}-\mathrm{n}$-Butanol for $1 \mathrm{~min}$ in glass homogenizer. The sample was centrifuged for $10 \mathrm{~min}$ at 2000rpm. The supernantphase was removed and added to Eppendorf reagent tubes containing $0.2 \mathrm{ml}$ of heptanes and $0,0.25 \mathrm{ml}$ of $\mathrm{Hcl}$. After $10 \mathrm{~min}$ of vigorous shaking the tube was centrifuged under same condition to separate two phases.

The aqueous phase was taken and O-phthaldialdehyde was added. The fluophore was developed by heating to $100^{\circ} \mathrm{C}$ for $10 \mathrm{~min}$ after the sample reached the equilibrium the intensity reading was measured at $360-470 \mathrm{~nm}$.

\section{RESULTS}

\section{Effects of EEFC and AEFC in EPM Model}

Ethanolic and aqueous extract of Ficus carica significantly increased mean number of entries and mean time spent by mice in open arms of elevated plus maze apparatus at the dose of 200 and $400 \mathrm{mg} / \mathrm{kg}$ with respect to control and exhibited a decrease in the mean time spent and significant decrease $(p<0.001)$ in the mean number of entries in the closed arm was observed when compared to the control, thereby producing anti-anxiety activity.

Table 2: Effect of EEFC and AEFC on Elevated plus maze.

\begin{tabular}{|c|c|c|c|c|c|}
\hline Group & Treatment & $\begin{array}{l}\text { Time spent in } \\
\text { open arm (sec) }\end{array}$ & $\begin{array}{l}\text { Time spent in } \\
\text { closed arm (sec) }\end{array}$ & $\begin{array}{l}\text { No. of entries in } \\
\text { open arm }\end{array}$ & $\begin{array}{l}\text { No. of entries } \\
\text { in closed arm }\end{array}$ \\
\hline I & Gum acacia $1 \%(10 \mathrm{ml} / \mathrm{kg})$ & $20.17 \pm 6.327$ & $230.0 \pm 13.60$ & $2.00 \pm 0.6325$ & $21.17 \pm 3.390$ \\
\hline II & Diazepam $(2 \mathrm{mg} / \mathrm{kg})$ & $\begin{array}{l}195.0 \pm 3.651 \\
a^{* * *}\end{array}$ & $\begin{array}{l}140.0 \pm 17.51 \\
\text { ans }\end{array}$ & $6.167 \pm 0.4773 \mathrm{a}^{* * *}$ & $\begin{array}{l}7.667 \pm 0.333 \\
a^{* * *}\end{array}$ \\
\hline III & EEFC (200 mg / kg) & $\begin{array}{l}38.33 \pm 3.33 \\
\text { ans bns }\end{array}$ & $\begin{array}{l}73.33 \pm 21.71 \\
\text { ansbns }\end{array}$ & $3.500 \pm 0.4282 \mathrm{a} * \mathrm{~b} * * *$ & $\begin{array}{l}3.500 \pm 0.4282 \\
a * * b^{*}\end{array}$ \\
\hline IV & $\mathrm{EEFC}(400 \mathrm{mg} / \mathrm{kg})$ & $\begin{array}{l}90.00 \pm 10.17 \\
\mathrm{a} * * * \text { bns }\end{array}$ & $\begin{array}{l}148.17 \pm 10.99 \\
\text { ansbns }\end{array}$ & $4.667 \pm 0.2108 \mathrm{a}^{* * *} \mathrm{~b}^{*}$ & $\begin{array}{l}12.00 \pm 1.291 \\
\mathrm{a} * \mathrm{~b}^{*}\end{array}$ \\
\hline V & AEFC (200 mg / kg) & $\begin{array}{l}96.67 \pm 11.67 \\
a * * \text { bns }\end{array}$ & $\begin{array}{l}80.83 \pm 23.75 \\
a^{* *} \text { bns }\end{array}$ & $3.667 \pm 0.2108 \mathrm{a}^{*} \mathrm{~b} * * *$ & $\begin{array}{l}5.50 \pm 1.648 \\
\mathrm{a}^{* * *} \text { bns }\end{array}$ \\
\hline VI & $\mathrm{AEFC}(400 \mathrm{mg} / \mathrm{kg})$ & $\begin{array}{l}168 \pm 5.270 \\
a^{* * *} \text { bns }\end{array}$ & $\begin{array}{l}96.67 \pm 43.743 \\
a^{* * *} \text { bns }\end{array}$ & $\begin{array}{l}5.500 \pm 0.2236 \mathrm{a}^{* * *} \\
\text { bns }\end{array}$ & $\begin{array}{l}10.33 \pm 1.116 \\
\mathrm{a} * * * \text { bns }\end{array}$ \\
\hline
\end{tabular}

The values were expressed as mean \pm SEM of 6 animals

Comparison were made between: Group I vs Group II, III, IV, V and VI which is considered as - a, Group II vs Group III, IV, V, VI which is considered as - b, statistical significance test for comparision was done by one way ANOVA followed by Dunnet's ' $t$ ' test. $\mathrm{p}^{*}<0.05, \mathrm{P}^{* *}<0.01, \mathrm{P} * * *<0.001 \mathrm{~ns}-$ non significance 
Table 3: Effect of EEFC and AEFC on T Maze baseline latency.

\begin{tabular}{|ll|lll|}
\hline Group & Treatment & No. of Base line latency & No. of Escape & No. of Avoidance \\
\hline I & Gum acacia $1 \%(10 \mathrm{ml} / \mathrm{kg})$ & $2.66 \pm 0.33$ & $7.66 \pm 0.33$ & $8.33 \pm 0.33$ \\
\hline II & Diazepam $(2 \mathrm{mg} / \mathrm{kg})$ & $5.33 \pm 0.33 \mathrm{a}^{*}$ & $2.50 \pm 0.22 \mathrm{a}^{* * *}$ & $5.83 \pm 0.30 \mathrm{a}^{* * *}$ \\
\hline III & EEFC $(200 \mathrm{mg} / \mathrm{kg})$ & $3.16 \pm 0.79$ ansbns & $7.33 \pm 0.21 \mathrm{ansb} * * *$ & $6.66 \pm 0.33 \mathrm{a}^{*} \mathrm{bns}$ \\
\hline IV & EEFC $(400 \mathrm{mg} / \mathrm{kg})$ & $4.96 \pm 0.36 \mathrm{a}^{*} \mathrm{bns}$ & $3.16 \pm 0.30 \mathrm{a}^{* * *} \mathrm{bns}$ & $3.00 \pm 0.44 \mathrm{a}^{* * *} \mathrm{~b}^{* * *}$ \\
\hline V & AEFC $(200 \mathrm{mg} / \mathrm{kg})$ & $3.15 \pm 0.79 \mathrm{ansbns}$ & $5.33 \pm 0.76 \mathrm{a}^{* *} \mathrm{~b}^{* * *}$ & $6.66 \pm 0.33 \mathrm{a}^{*} \mathrm{bns}$ \\
\hline VI & AEFC $(400 \mathrm{mg} / \mathrm{kg})$ & $5.00 \pm 0.36 \mathrm{a}^{*} \mathrm{bns}$ & $2.83 \pm 0.30 \mathrm{a}^{* * * b n s}$ & $2.50 \pm 0.56 \mathrm{a}^{* * *} \mathrm{~b}^{* * *}$ \\
\hline
\end{tabular}

The values were expressed as mean \pm SEM of 6 animals

Comparison were made between: Group I vs Group II, III, IV, V and VI which is considered as - a, Group II vs Group III, IV, V, VI which is considered as - b, statistical significance test for comparison was done by one way ANOVA followed by Dunnet's ' $t$ ' test. $\mathrm{p}^{*}<0.05, \mathrm{P} * *<0.01, \mathrm{P} * * *<0.001 \mathrm{~ns}-$ non significance

Table 4: Effect of EEFC and AEFC on Hole board.

\begin{tabular}{|lllll|}
\hline Group & Treatment & No. of Line crossing & No. of Head Dipping & No. of rearing \\
\hline I & Gum acacia $1 \%(10 \mathrm{ml} / \mathrm{kg})$ & $24.33 \pm 2.30$ & $4.500 \pm 1.02$ & $28.67 \pm 3.94$ \\
\hline II & Diazepam $(2 \mathrm{mg} / \mathrm{kg})$ & $41.50 \pm 2.68 \mathrm{a}^{* * *}$ & $22.00 \pm 3.27 \mathrm{a}^{* * *}$ & $9.6670 \pm 0.49 \mathrm{a}^{* * *}$ \\
\hline III & EEFC $(200 \mathrm{mg} / \mathrm{kg})$ & $37.33 \pm 2.78 \mathrm{a}^{* *}$ bns & $4.167 \pm 0.54 \mathrm{ansb} \mathrm{b}^{* * *}$ & $19.50 \pm 1.94 \mathrm{a}^{* *} \mathrm{~b}^{* * *}$ \\
\hline IV & EEFC $(400 \mathrm{mg} / \mathrm{kg})$ & $23.00 \pm 1.43$ ansb $* * *$ & $13.83 \pm 1.10 \mathrm{a}^{* *} \mathrm{~b}^{* *}$ & $9.000 \pm 0.51 \mathrm{a}^{* * *}$ bns \\
\hline V & AEFC $(200 \mathrm{mg} / \mathrm{kg})$ & $37.50 \pm 2.70 \mathrm{a}^{* *}$ bns & $3.667 \pm 0.84 \mathrm{ansb} \mathrm{b}^{* * *}$ & $10.67 \pm 10.67 \mathrm{a}^{* * *}$ bns \\
\hline VI & AEFC $(400 \mathrm{mg} / \mathrm{kg})$ & $21.83 \pm 1.55$ ans $\mathrm{b}^{* * *}$ & $11.83 \pm 1.01 \mathrm{a}^{*} \mathrm{~b}^{* * *}$ & $8.667 \pm 0.55 \mathrm{a}^{* * *}$ bns \\
\hline
\end{tabular}

The values were expressed as mean \pm SEM of 6 animals

comparison was made between: Group I vs Group II, III, IV, V and VI which is considered as - a, Group II vs Group III, IV, V, VI which is considered as - $b$, statistical significance test for comparison was done by one way ANOVA followed by Dunnet's ' $t$ ' test. $\mathrm{p}^{*}<0.05 \mathrm{P} * *<0.01 \mathrm{P} * * *<0.001$ ns-non significance

Table 5: Effect of EEFC and AEFC on nor adrenaline, serotonin and dopamine in mice brain.

\begin{tabular}{|lllll|}
\hline Group & Treatment & $\begin{array}{l}\text { Nor Adrenaline }(\mathbf{n g} / \mathrm{gm} \\
\text { of brain tissue) }\end{array}$ & $\begin{array}{l}\text { Serotonin } \\
\text { (ng/gm of brain tissue) }\end{array}$ & $\begin{array}{l}\text { Dopamine } \\
\text { (ng/gm of tissue) }\end{array}$ \\
\hline I & Gum acacia $1 \%(10 \mathrm{ml} / \mathrm{kg})$ & $2.633 \pm 0.07$ & $2.385 \pm 0.08$ & $1.417 \pm 0.10$ \\
\hline II & Diazepam $(2 \mathrm{mg} / \mathrm{kg})$ & $0.775 \pm 0.05 \mathrm{a}^{* * *}$ & $3.293 \pm 0.16 \mathrm{a}^{* *}$ & $0.946 \pm 0.37 \mathrm{ans}$ \\
\hline III & EEFC $(200 \mathrm{mg} / \mathrm{kg})$ & $2.373 \pm 0.08 \mathrm{ansb}^{* * *}$ & $2.928 \pm 0.21 \mathrm{ansbns}$ & $1.127 \pm 0.1 \mathrm{ansbns}$ \\
\hline IV & EEFC $(400 \mathrm{mg} / \mathrm{kg})$ & $1.962 \pm 0.05 \mathrm{a}^{* * *} \mathrm{~b}^{* * *}$ & $3.212 \pm 0.24 \mathrm{a}^{*} \mathrm{bns}$ & $1.023 \pm 0.02 \mathrm{ansbns}$ \\
\hline V & AEFC $(200 \mathrm{mg} / \mathrm{kg})$ & $2.252 \pm 0.08 \mathrm{a}^{* *} \mathrm{~b}^{* * *}$ & $2.925 \pm 0.22 \mathrm{ansbns}$ & $1.025 \pm 0.04 \mathrm{ansbns}$ \\
\hline VI & AEFC $(400 \mathrm{mg} / \mathrm{kg})$ & $2.375 \pm 0.008 \mathrm{ansb}^{* * *}$ & $3.124 \pm 0.18 \mathrm{a}^{*} \mathrm{bns}$ & $1.026 \pm 0.05 \mathrm{ansbns}$ \\
\hline
\end{tabular}

The values were expressed as mean \pm SEM of 6 animals

Comparison were made between: Group I vs Group II, III, IV,V and VI which is considered as - a, Group II vs Group III, IV, V, VI which is considered as - $b$, statistical significance test for comparison was done by one way ANOVA followed by Dunnet's ' $t$ ' test.

$\mathrm{p}^{*}<0.05, \mathrm{P} * *<0.01, \mathrm{P} * * *<0.001$ ns-non significance

Ethanolic and aqueous extract of Ficus carica significantly increased mean number of entries and mean time spent by mice in open arms of elevated plus maze apparatus at the dose of 200 and $400 \mathrm{mg} / \mathrm{kg}$ with respect to control and exhibited a decrease in the mean time spent and significant decrease $(p<0.001)$ in the mean number of entries in the closed arm was observed when compared to the control, thereby producing anti-anxiety activity. The results were shown in Table 2.

\section{Effects of EEFC and AEFC in T-Maze Model}

A significant increase $(\mathrm{p}<0.05)$ in the base line latency and decrease $(p<0.001)$ in the escape and avoidance ( $p$ $<0.001$ ) of the T-maze were observed in the Diazepam
$2 \mathrm{mg} / \mathrm{kg} / \mathrm{i} . \mathrm{p}$ treated animals when compared to the control animals.

Both the extract of Ficus carica exhibited significant increase in the base line latency and also a decrease in the escape whereas significant decrease $(p<0.05)$ in the avoidance of the T-maze was observed compared to the control and with standard drug diazepam. The results were shown in Table 3.

\section{Effects of EEFC and AEFC in Hole-Board Model}

The number of line crossing, head dipping and rearing were increased significantly in the Diazepam $2 \mathrm{mg} / \mathrm{kg} / \mathrm{i} . \mathrm{p}$ treated animals when compared to the control animals. 
The EEFC and AEFC at both the doses exhibited significant increase $(p<0.01)$ in the number of line crossing, an increase (ns) in head dipping and significant increase $(p<0.01)$ in rearing was observed when compared to the control as well as diazepam.

An agent that decreases head dipping, line crossing and rearing reveals a sedative behavior. Anxiolytics have been shown to increase these parameters. In the present study, EEFC and AEFC (200 and 400mg/kg) increased headdipping counts, number of line crossing and rearing showed the anxiolytic activity. The results were shown in Table 4.

\section{Effect of EEFC and AEFC in the brain neurotransmitter levels}

\section{Nor-adrenaline level in mice brain}

The standard drug diazepam $2 \mathrm{mg} / \mathrm{kg} / \mathrm{p} .0$ exhibited a significant decrease $(\mathrm{p}<0.001)$ in the brain nor-adrenaline level was observed when compared to the control animals.

Both the extracts at the dose of 200 and $400 \mathrm{mg} / \mathrm{kg} / \mathrm{p} . \mathrm{o}$ exhibited a decrease (ns) in the brain nor-adrenaline levels when compared to the control animals whereas the same dose exhibited a significant decrease $(\mathrm{p}<0.001)$ noradrenaline levels was observed when compared to the DZA, standard drug treated animals. The results were shown in Table 5.

\section{Serotonin level in mice brain}

The EEFC and AEFC at the dose of 200 and $400 \mathrm{mg} / \mathrm{kg} / \mathrm{p} . \mathrm{o}$ dose exhibited an increase (ns) in the brain Serotonin levels was observed when compared to the control and DZA, standard drug treated animals. The results were shown in Table 5.

\section{Dopamine level in mice brain}

The standard drug diazepam $2 \mathrm{mg} / \mathrm{kg} / \mathrm{p}$.o exhibited a decrease in the brain dopamine level when compared to the control animals.

The EEFC and AEFC at the dose of 200 and $400 \mathrm{mg} / \mathrm{kg} / \mathrm{p} . \mathrm{o}$ dose level exhibited a decrease in the brain dopamine levels was observed when compared to the control and DZA, standard drug treated animals. The results were displayed in Table 5.

\section{Histopathological analysis of mice brain}

The mice brain tissue in control group had shown intact cell architecture. There were no significant alterations observed in standard group treated with diazepam and tissues showed a normal picture or brain cells and less proliferation. The mice treated with EEFC $200 \mathrm{mg} / \mathrm{kg}$ showed the mildest lesions with some swelling of myelin sheaths, whereas the group treated with EEFC $400 \mathrm{mg} / \mathrm{kg}$ and AEFC 200 and $400 \mathrm{mg} / \mathrm{kg}$ showed no pathological damages and cellular architecture are intact (Figure 1).

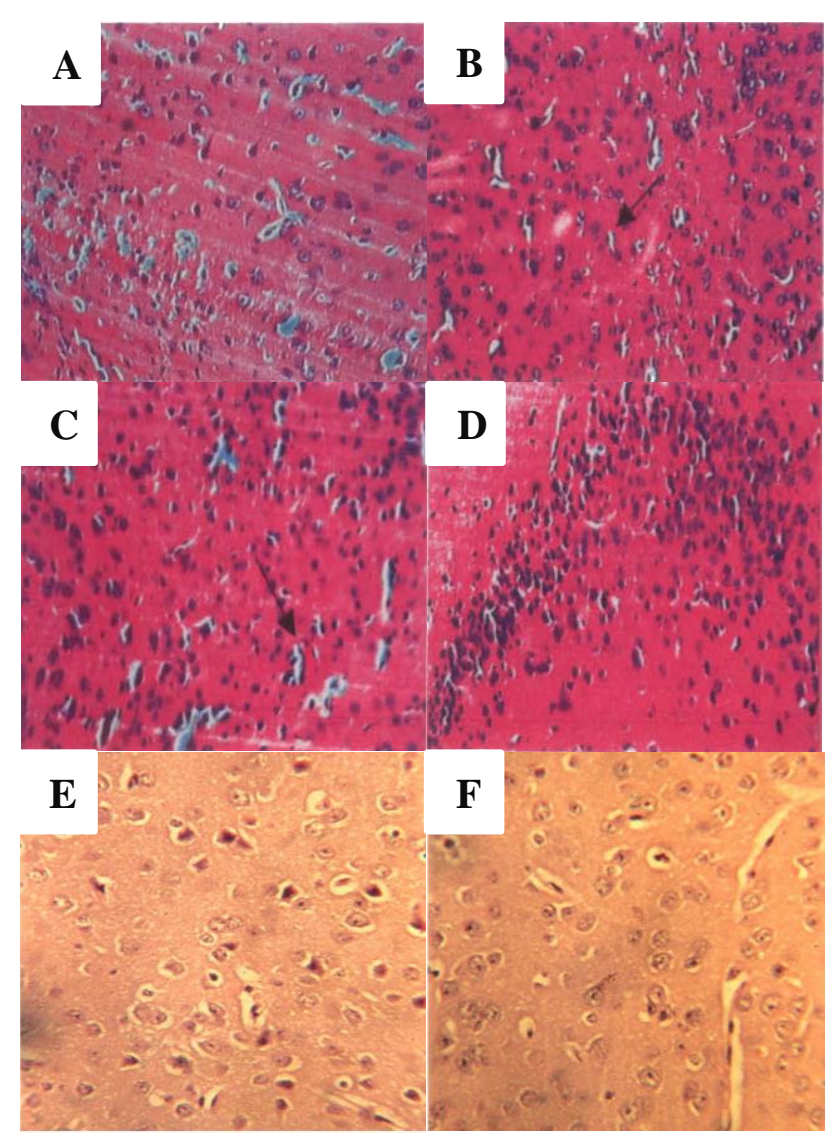

(A): Control, (B): diazepam $2 \mathrm{mg} / \mathrm{kg} / \mathrm{p.o}$, (C): EEFC 200mg/kg/p.o, (D): 400mg/kg/p.o, (E): AEFC 200mg/kg/p.o, (F): AEFC 400mg/kg/p.o

Figure 1: Histopathological analysis of mice brain.

\section{DISCUSSION}

According to World Health Organization report approximately 450 million people suffer from a mental or behavioral disorder, yet only small minority of them receives even the most basic treatments. This amounts to $12.3 \%$ of the global burden of disease, and will rise to $15 \%$ by $2020 .{ }^{1}$ Individuals aged between 10 and 25 years are at highest risk for developing an anxiety condition.

The ideal anti-anxiety drugs would suppress all the symptoms like irritability, uneasiness, jumpiness, feelings of apprehension, rapid or irregular heartbeat, stomach ache, nausea, faintness, and breathing problems associated with it, without causing any unwanted effects. Benzodiazepines are the major classes of compounds used in anxiety and they remain the most commonly prescribed treatment for anxiety. However, the clinical uses of BZD are limited by their side effects such as drowsiness and loss of coordination. Fatigue and mental slowing or confusion, vertigo, alterations in sexual functions can also occur with BZD. $^{2}$ 
The recognition of anxiolytic effects of nonbenzodiazepine azapirones agents, which act as $5-\mathrm{HT} 1_{\mathrm{A}}$ partial agonists, such as buspirone, gepirone, and ipsapirone and their therapeutic role in clinical anxiety and mood disorders has further focused attention on the 5$\mathrm{HT} 1_{\mathrm{A}}$ receptor. Although the azapirones interact with other neurotransmitter systems such as the dopaminergic and noradrenergic, they display nanomolar affinity for 5$\mathrm{HT} 1_{\mathrm{A}}$ receptor sites.

It is estimated that, about $43 \%$ of anxiety sufferers use some form of complementary therapy. The most popular treatments include herbal medicines. Similarly, anxiety disorders are amongst the most common reason for people to try herbal medicines. ${ }^{14}$ Therefore, the development of new medications possessing anxiolytic effect without the complication of BZD would be of great importance in the treatment of anxiety-related disorders. Medicinal plants are a good source to find new remedies for these disorders. ${ }^{15}$

The rationale for herbal medicine is likely to be based on the activity of plant or its chemical constituents, to interact in the context of the gut and body tissues, to affect bioavailability.

Ficus carica Linn is commonly referred as "Fig" are used in the native system of medicine in different disorders throughout the world. HPTLC evidenced the presence of flavanoids in the active extract. Flavanoids have recently increased the importance because they have been identified as a new type of ligand with in-vivo anxiolytic properties. Flavanoids is a group of polyphenolic compounds, have been demonstrated by a number of groups to be centrally active, possessing efficacies for a number of receptor systems in the CNS. Ligands upon binding to the BZDs, $\mathrm{GABA}_{\mathrm{A}}$ receptor complex exert pharmacologically and clinically important profiles including anxiolytics, anti-convulsion, muscle-relaxation, sedation, the reduction of neuronal oxidative metabolism and estrogenic effects.

On the basis of these considerations, it was the purpose of this study to characterize the anxiolytic-like activity of an aqueous and ethanolic extracts of Ficus carica linn fruit extracts using different validated animal models for anxiety based on exploratory behavior of rodents.

The present work demonstrated the anxiolytic effects in various models like EPM, T-maze, and Hole board methods. The neurotransmitters like Dopamine, Noradrenaline, Serotonin were estimated to elucidate the neurochemical mechanisms using standard procedures.

The EPM model is based on exploration in a novel environment leading to the generation of approach avoidance conflict behavior, which is highly sensitive to the $\mathrm{GABA}_{\mathrm{A}}$ benzodiazepine receptor complex. ${ }^{16}$ This animal model is considered one of the most widely validated tests for assaying sedative and anxiolytic substances such as the benzodiazepines. ${ }^{17}$ In EPM rodents, mice will normally prefer to spend much of their allotted time in the closed arms. This preference appears to reflect an aversion towards open arm that is generated by the fears of the open spaces. $^{18}$ Anxiolytic compounds, by decreasing anxiety, increase the open arm exploration time as well as the number of entries into the open arm.

In this study, we observed both EEFC and AEFC at the dose of 200 and $400 \mathrm{mg} / / \mathrm{kg} / \mathrm{p}$.o induced significant increases in the both number of entries and time spent in the open arm whereas the number of entries and time spent in the closed arms were reduced in the EPM model. The extracts produced the anxiolytic activity probably acting through GABAABZA receptor agonist.

Elevated T-maze apparently generates different types of fear/anxiety, resulting in complex variability of anxiolytic agents. EEFC and AEFC at the doses of 200 and 400 $\mathrm{mg} / \mathrm{kg}$ p.o showed a significant increase in baseline latency and decrease in escape and avoidance when compared to the control animals, which support the anxiolytic activity. In T-maze model CRF, ACTH and vasopressin are involved in differential enhancement of memory of helpless condition.

The hole-board test provides a simple method for measuring the response of an animal to an unfamiliar environment and is widely used to assess emotionality, anxiety and/or responses to stress in animals. In the holeboard model a significant increase in the exploratory behavior like head-dipping and line crossing, rearing was observed after treatment with EEFC and AEFC at the doses of 200 and $400 \mathrm{mg} / \mathrm{kg} / \mathrm{p}$.o. Thus reinforcing the hypothesis that it has anxiolytic activity.

Fear and anxiety are related to the catecholaminergic and serotonergic systems which are important in "alarm reactions" and "conflict behavior".

Altered noradrenergic signalling is linked to anxiety disorders. Sustained stimulation of locus ceruleus result in manifestation of anxiety symptoms such as tremor. Stressinduced release of NE facilitates a number of anxiety-like behavioral responses. This nucleus projects to multiple brain areas, including the limbic system, hypothalamus and cortex. Stress increases the turnover of NE in the brain and this can be inhibited by anti-anxiety agents. Therefore, the end result of most clinicially efficacious anxiolytic agents is believed to be associated with decreasing noradrenergic neurotransmissions, which is proven by the $\beta$ adrenergic blockers for treatment of anxiety.

Anxiety is usually associated with increased endogenous 5-HT, whereas anxiolytics tends to be associated with decreased endogenous 5-HT. Buspirone, gepirone and ipsapirone 5-HT ligands had an anxiolytic effect on mice. 5-HT receptors are also heterorecptors and modulate the release of other neurotransmitters. Serotonergic neurons are implicated in the alteration of energy, sleep, mood and 
cognitive function in anxiety. Among the symptoms of serotonin deficiency are anxiety, worry, obsessions, compulsions, panic, phobias, insomnia, depression, and suicidal thoughts. In the present study both the extracts showed a significant increase in the 5-HT level in the brain homogenate.

Dopamine has been considered to play a role in social phobia and may be related to the social-specific nature of this anxiety disorder, particularly where dopaminergic activation involves D2 receptors. Reductions in D2 receptor binding have been noted in primates that exhibit subordinate and introverted/fearful behaviors. In the present study both the extracts showed a significant increase in the dopamine level in the brain homogenate

Benzodiazepines exert their anxiolytic effects by enhancing GABA activities in GABAA receptor results in increased chloride influx into neurons including noradrenergic which leads to hyperpolarization and decreased excitability. Decreased the firing rate of noradrenergic neurons, a phenomenon that explains their anxiolytic capacity.

In this study we have estimated the brain neurotransmitters such as serotonin, nor-adrenaline and dopamine. Both the extracts at the doses of 200 and $400 \mathrm{mg} / \mathrm{kg}$ showed an increase in the serotonin and nor-adrenaline levels in the brain concurrent decrease in dopamine level, further confirms the anxiolytic action of Ficus carica Linn.

The Ficus carica Linn extracts showed the presence of flavanoids. Flavanoids have been recently implicated for various pharmacological activities and they have been identified as a new type of ligand with in vivo anxiolytic properties. Different plant species utilized in traditional medicine have been submitted to neuropharmacological evaluation demonstrated the involvement of flavones likechrysin and apigenin, have an anxiolytic effect in rodents exposed to behavioral tests. Apparently, these compounds modulate the GABAergic system to produce an anxiolytic effect. Thus we suggest that, these flavonoid mixtures like tilirosiderutin, quercitrin, kaempferol and quercetin may be responsible for the anxiolytic effect of Ficus carica Linn.

\section{CONCLUSION}

The present study demonstrated that the both the extracts of fruits of Ficus carica Linn. possess the anxiolytic activity. The flavonoids present in this extracts responsible for its anxiolytic activity. Furthermore, there is need to find out the exact mechanism by which the plant exerts the anxiolytic activity.

Funding: No funding sources Conflict of interest: None declared

Ethical approval: The study was approved by the Institutional Animal Ethics Committee of C.L. Baid Metha College of Pharmacy, Okkiyam Thuraipakkam, Chennai

\section{REFERENCES}

1. Reynolds EH. Brain and mind: a challenge for WHO. Lancet. 2003;361:1924-5.

2. Tripathi KD. Anti anxiety drugs In: Essentials of Medical Pharmacology, $6^{\text {th }}$ Edn. Jaypee Brothers Medical Publishers; 2008:449.

3. Kirtikar KR, Basu BD. Indian medicinal plants. International Book Distributors, India; 1996:2(3).

4. Nadkarni KM, Nadkarni AK. Indian material medica. Popular Prakashan, India. 1995;1.

5. Chawla A, Kaur R, Sharma AK. Ficus carica Linn.: A review on its pharmacognostic, phytochemical and pharmacological aspects. International Journal of Pharmaceutical and Phytopharmacological Research. 2017;1(4):215-32.

6. Serraclara A, Hawkins F, Perez C, Domínguez E, Campillo JE, Torres MD. Hypoglycemic action of an oral fig-leaf decoction in type-I diabetic patients. Diabetes Research and Clinical Practice. 1998;39(1):19-22.

7. de Amorin A, Borba HR, Carauta JP, Lopes D, Kaplan MA. Anthelmintic activity of the latex of Ficus species. Journal of ethnopharmacology. 1999;64(3):255-8.

8. Pérez C, Canal JR, Campillo JE, Romero A, Torres MD. Hypotriglyceridaemic activity of Ficus carica leaves in experimental hypertriglyceridaemic rats. Phytotherapy Research. 1999;13(3):188-91.

9. Asadi F, Pourkabir M, Maclaren R, Shahriari A. Alterations to lipid parameters in response to fig tree (Ficus carica) leaf extract in chicken liver slices. Turkish Journal of Veterinary and Animal Sciences. 2006;30(3):315-8.

10. Kulkarni SK, Reddy DS. Animal behavioral models for testing antianxiety activity. Meth Find Exp Clin Pharmacol. 1996;18:219-40.

11. Komada M, Takao K, Miyakawa T. Elevated Plus Maze for Mice. Journal of Visualized Experiments: JoVE. 2008;22:1088.

12. Graeff FG, Netto CF, Zangrossi H Jr. The elevated Tmaze as an experimental model of anxiety. Neurosci Biobehav Rev. 1998;23(2):237-46.

13. File $S$, Pellow $S$. The effect of triazolobenzodiazepines in two animal tests of anxiety and on the hole-board. Br J Pharmacol. 1985;86:729-35.

14. Andreatini R, Sartori VA, Seabra ML, Leite JR. Ernst. Herbal remedies for anxiety a systematic review of controlled clinical trials. Phytomed. 2004;1(4):3.

15. Emamghoreishi M, Khasaki M, Aazam MF. Coriandrum sativum: evaluation of its anxiolytic effects in the elevated plus maze. Journal of Ethanopharmacology. 2005;96:365-70.

16. Carey G, Gottesman I. Twin and family studies of anxiety, phobic, and obsessive disorders. In: Klein DF, Rabkin JG. Anxiety: New Research and Changing Concepts. New York: Raven Press; 2000.

17. Lochner C, Mogotsi M, du Toit PL, Kaminer D, Niehaus DJ, Stein DJ. Quality of life in anxiety disorders: a comparison of obsessive-compulsive 
disorder, social anxiety disorder, and panic disorder.

Psychopathology. 2003;36(5):255-62.

18. Denys D, Van Nieuwerburgh F, Deforce D, Westenberg H. Association between the dopamine D receptor TaqI A2 allele and low activity COMT allele with obsessive-compulsive disorder in males. Eur Neuropsychopharmacol. 2006;16(6):446-50.

Cite this article as: Chandrashekar $\mathrm{K}$, Amudha $\mathrm{P}$, Venkataraman S. Anxiolytic activity of ethanolic and aqueous extract of Ficus carica Linn fruits in swiss albino mice. Int J Basic Clin Pharmacol 2017;6:2043-50. 